\title{
305 Is real-time CMR really sensitive and specific for pericardial constriction?
}

\author{
Andrew Flett*, Carolyn McCarthy, Martin Hayward, Mark A Westwood and \\ James C Moon
}

Address: The Heart Hospital, London, UK

* Corresponding author

from I th $^{\text {th }}$ Annual SCMR Scientific Sessions

Los Angeles, CA, USA. I-3 February 2008

Published: 22 October 2008

Journal of Cardiovascular Magnetic Resonance 2008, I0(Suppl I):A108 doi:I0.II86/I532-429X-I0-SI-A 108

This abstract is available from: http://jcmr-online.com/content/I0/SI/AI08

(c) 2008 Flett et al; licensee BioMed Central Ltd.

\section{Introduction}

CMR has excellent ability to detect the anatomical changes of pericardial thickening. It has been proposed that the physiological changes of constriction manifested by ventricular:ventricular interaction are also well detected using real-time dynamic CMR during inspiration/expiration.

\section{Hypothesis}

That real-time dynamic CMR would be sensitive and specific for pericardial constriction.

\section{Methods}

42 consecutive patients referred for CMR without any clinical/echo/MRI features of constriction were compared with 8 individuals confirmed operatively to have had constriction using real-time SSFP cine imaging during inspiration/expiration in a short axis view.

\section{Results}

$88 \%$ (7 of 8 ) of confirmed constriction patients vs $5 \%$ ( 2 of 42) patients without constriction had marked septal flattening $(\mathrm{p}<0.001)$. The accuracy, sensitivity and specificity were $83 \%, 78 \%$ and $83 \%$ respectively, Figure 1 . Compared to the average control population, the 2 nonconstriction patients with marked septal flattening were younger ( 38 vs $61, \mathrm{p}<0.001$ ) and were both endurance athletes. $12 \%$ ( 5 of 42 ) of patients without constriction had subtle septal flattening (arbitrarily defined as an inspiratory septal deviation away from baseline of less than the thickness of the septum). The one constriction patient without marked septal flattening was complex with additional pathology (anomalous systemic and pulmonary venous drainage), raising doubts about the surgical gold-standard chosen.

\section{Conclusion}

Real-time dynamic CMR is indeed highly sensitive and specific for pericardial constriction provided that a) the septal flattening is marked and b) the individual under investigation is not a young athlete, where marked dynamic septal flattening can be normal. 


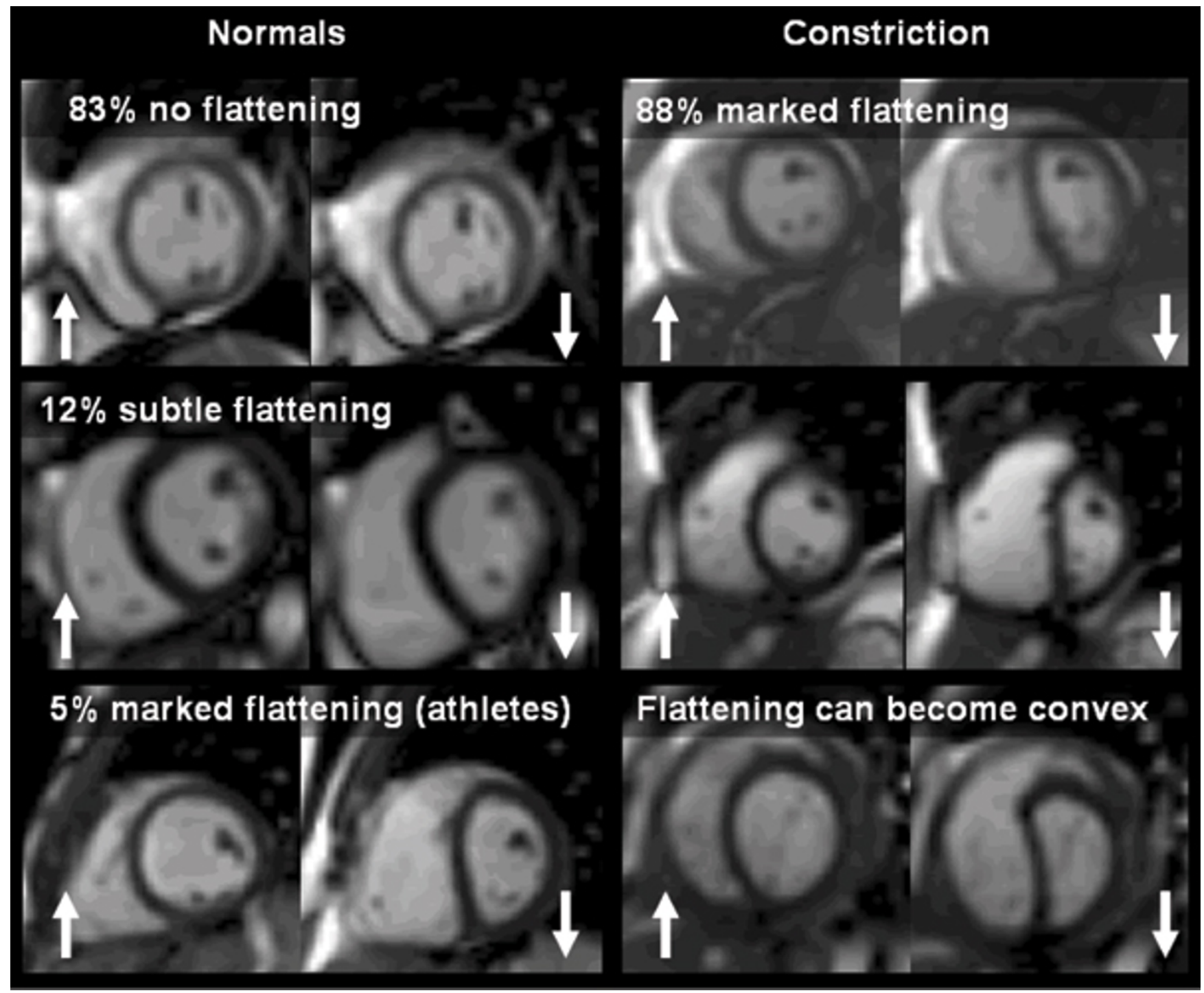

Figure I

Real-time dynamic CMR is indeed highly sensitive and specific for pericardial constriction provided that a) only marked septal flattening is counted and b) the individual under investigation is not an athlete, where marked inspiratory septal flattening can be normal.

\begin{tabular}{|} 
Publish with BioMed Central and every \\
scientist can read your work free of charge \\
"BioMed Central will be the most significant development for \\
disseminating the results of biomedical research in our lifetime. " \\
Sir Paul Nurse, Cancer Research UK \\
Your research papers will be: \\
• available free of charge to the entire biomedical community \\
• peer reviewed and published immediately upon acceptance \\
• cited in PubMed and archived on PubMed Central \\
• yours - you keep the copyright \\
Submit your manuscript here: \\
http://www.biomedcentral.com/info/publishing_adv.asp
\end{tabular}

